\title{
Determinants Factors of High-risk Sexual Behavior Pregnancy among Adolescent in Indonesia
}

\author{
Cecep Eli Kosasih ${ }^{1^{*}}$, Tetti Solehati ${ }^{2}$, Wahyu Utomo ${ }^{3}$, Heru Heru ${ }^{3}$, Amalia Rizqi Sholihah ${ }^{2}$ \\ ${ }^{1}$ Department of Critical Nursing, Faculty of Nursing, Universitas Padjadjaran, Bandung, Indonesia; ${ }^{2}$ Department of Maternity \\ Nursing, Faculty of Nursing, Universitas Padjadjaran, Bandung, Indonesia; ${ }^{3}$ First Researcher of BKKBN Research Center, \\ Jakarta, Indonesia
}

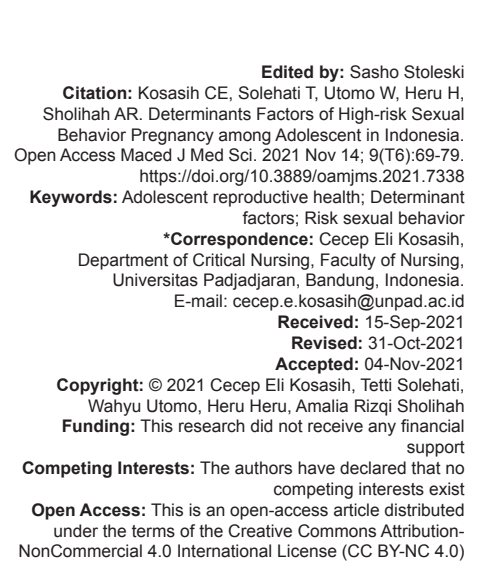

Abstract

BACKGROUND: The vulnerability of adolescent lifestyles, especially sexual behavior among adolescents, which causes an increase in pregnancy and early marriage.

AIM: This study aimed to analyze the determinants of high-risk sexual behavior among adolescents in Indonesia.

METHODS: A correlational analytic research design was used with a cross-sectional approach using secondary data for the 2017 Indonesian demographic and health survey data (IDHS). The data collection was carried out through filling in the instruments developed by the 2017 IDHS. The data were analyzed using percentages, Chi-square test, and logistic regression. The study population was all adolescents, totaling 9,971 women and 12,612 single men aged 15-24 and living in Indonesia in the 2017 IDHS. The sampling technique used total sampling. Time of research: August-November 2020. Place: research locations in 34 provinces in Indonesia.

RESULTS: In male respondents, it was shown that the factors most influencing high-risk sexual behavior in adolescents were age $(p=0.000)$, knowledge $(p=0.003)$, place of residence $(p=0.000)$, discussion before wet dreams $(p=0.000)$, age at first wet dream $(p=0.000)$, age at first dating $(p=0.019)$, and internet usage $(p=0.000)$. Meanwhile, female respondents indicated that the most influential factors were age $(p=0.000)$ and place of residence $(p=0.032)$.

CONCLUSION: Boys have many factors that influence high-risk sexual behavior than girls. Information on determinant factors of high-risk adolescent sexual behavior can be used as a basis for developing policies for developing interventions in solving problems of premarital pregnancy due to high-risk sexual behavior among adolescents.

\section{Introduction}

Indonesia is currently entering the demographic bonus era due to changes in the age structure of the population, where there has been a decrease in the ratio of the non-productive population (aged $<15$ years and $\geq 65$ years) to the productive population (aged 15-64 years) [1]. The productive population in this era is dominated by generation $\mathrm{Y}$ (millennial generation) and generation $\mathrm{Z}$ (youth). The population of adolescents aged 15-24 years is around $17 \%$ of Indonesia's population, which is projected to continue to grow [2]. Population census data in 2010 shows the number of adolescents is quite high, reaching 64 million (27.6\%) [3].

Youth according to the 2017 Indonesian demographic and health survey data (IDHS) are unmarried women and men aged 15-24 years [2]. Adolescence is a period of transition from childhood to adulthood, a time of seeking identity, and trial and error [4], [5]. Indonesian adolescents are currently experiencing a rapid social change from a traditional society to a modern one, which is changing their norms, values and lifestyle [6]. This is a risk of problems including reproductive health problems such as high-risk sexual behavior. The current generation of adolescents is often faced with various acute problems such as the breakdown of adolescent relationships and the proliferation of immoral acts (access to pornography, free sex, abortion). Sexual behavior in adolescents is one of the three basic threats to Adolescent Reproductive Health (KRR) or the KKR Triad. This problem is one of the triggers for the relatively high age-specific fertility rate aged 15-19 years.

Data from the United Nations Population Division, in 2007, showed that as many as 592,975,000 teenagers aged 10-19 years in the world were estimated to have $47 \%$ become sexually active [7]. High-risk sexual behavior among unmarried adolescents tends to increase. SKRRI 2007 data found that 15\% of boys and $20 \%$ of girls started dating at the age of $12-14$ years [8] and increased in 2012 to $25 \%$ for boys and $26 \%$ for girls [9]. According to SDKI data (2017), adolescents start dating at the age of $15(40 \%)$ by engaging in behaviors such as hugging, kissing lips, 
touching each other, and having sexual intercourse [2]. According to SKKRI (2012), it was found that adolescents during dating hold hands ( $72 \%$ of girls, $80 \%$ of boys), kiss (48\% of boys, $30 \%$ of girls, and feel sensitive body parts (30\% of boys, $6 \%$ of girls) [9]. This constitutes a high risk of premarital sex which leads to pregnancy which often ends in abortion. More than $12 \%$ of young women experience unwanted pregnancies and $23 \%$ end up aborting the pregnancy [2].

$\mathrm{KRR}$ is one of the four priority components of the National Reproductive Health [10]. The KRR program is one of the Population Family Planning and Family Development Programs that focuses on increasing the knowledge of adolescents, one of which is preventing early marriage and unwanted pregnancy [2]. To achieve this, the National Population and Family Planning Board (BKKBN) has created a Family Development, Population and Family Planning (Bangga Kencana) program. Several strategic issues that are developing and still need attention in the implementation of the 2020-2024 Bangga Kencana program include: new demands in building families for some communities (millennial and generation Z), lack of understanding of youth and families about planning/preparing for family life, as well as the inadequate management of various types of media to increase understanding and change in attitudes and behavior in support of the Bangga Kencana program [11].

Many factors influence the knowledge, attitudes, and behavior of adolescents. Adolescents often experience KRR problems due to the lack of adequate information, especially knowledge of KRR and preparation of family life [2]. Indonesia still experiences less even distribution of reproductive health promotion [12]. The lack of information obtained by adolescents has an impact on their level of knowledge, attitudes, and behavior. Knowledge was one of the factors associated with risky behavior among adolescents in Indonesia [13], [14]. In addition to the level of knowledge, education level, information sources, and parenting styles were also associated with early marriage [15]. Individual characteristic factors are such as age [16], use of social media such as the internet, newspapers, radio [17], [18], family norms and smartphone [19], [20], gender and peers [21], [22], [23] known to influence adolescent behavior. Meanwhile, the socio-demographic factors of parents (employment, education, family income) have a relationship with attitudes in adolescents [24].

The increasing number of adolescents with problems will interfere with the achievement of the tasks of adolescent growth and development [3]. It needs to be the attention of the government and various related parties, given that the current KRR problem in Indonesia is currently the main problem faced by adolescents. The problem of high-risk sexual behavior is a reflection of Indonesia's future which impacts on health problems and other aspects, both biopsychosocial and economic.
Sexual issue is now one of the government's priorities. The magnitude of the impact that will be borne due to the KRR problem for future lives, the government is committed to suppressing the incidence of KRR problems with various programs including the implementation of KKR education through the Bangga Kencana program.

Based on the technocratic design of the 2020-2024 National Medium Term Development Plan and the president's direction, RJPM is directed at increasing quality human resources who are competitive capable of building the character of the Nation through the Mental Revolution and Cultural Development. In achieving these goals, policy support is needed, one of which is through the KRR to support the Priority Program Increasing Access and Quality of Health Services, and Strengthening the Quality of Families [11]. Strengthening the quality of the family is indicated by a decrease in the median age at first marriage for women. The age at marriage in adolescents can be controlled by adequate exposure to KRR in adolescents.

The existence of adolescents is a national asset that the government and society should pay attention to in a system manner so that they can optimize their developmental tasks according to their age stages. Seeing the huge number, teenagers as the nation's next generation need to be prepared to become human beings who are physically, spiritually, mentally and spiritually healthy. But in fact, various studies show that adolescents have very complex problems along with the transitional period experienced by adolescents. To overcome this problem, it is necessary to analyze what factors can influence high-risk sexual behavior in adolescents, as well as which factors influence this behavior the most. The research results are expected to bea referenceforpolicy makers in developing appropriate interventions to prevent high-risk sexual behavior in adolescents. So that pregnancy in adolescents and early marriage can be resolved immediately. The purpose of this study was to analyze the determinants (demographic, individual, environmental, predisposing, enabling, and driving factors) associated with high-risk sexual behavior among adolescents in Indonesia. This research is expected to be useful as a recommendation material for decision makers/stakeholders in an effort to produce evidence-based policies to prevent risky sexual behavior in adolescents, the basic material in developing an intervention model for KKR service programs by various sectors in Indonesia, and as a reference base for stakeholders to develop a strategic solution model for Bangga Kencana.

\section{Methods}

The design of this research was correlational analytic with cross sectional approach. Data collection 
was carried out at once at 1 time, carried out in Indonesia using secondary data obtained from the IDHS: KKR 2017. Research was conducted from August-November 2020 with ethical permission from ICF International with ICF Prohect Number 132989.0.000. The population in this study were all adolescents totaling 9,971 women and 12,612 single men aged 15-24 and living in 34 provinces in Indonesia based on the 2017 IDHS. The sampling technique used total sampling. Inclusion Criteria: girls and boys aged 15-24 years, live in Indonesia, and have complete data on the required variables. Exclusion criteria: women and men aged <15 years and over 24 years and had incomplete data.

The dependent variable in this study is high-risk sexual behavior in adolescents. While the independent variables are: age, gender, level of education, economic dimension, area of residence, current youth activities, age at first menstruation, discussion activities before having the first menstruation, age for first wet dreams, and discussion activities before first menstruation, having had wet dreams, age at first dating, age at first sexual intercourse, sources of information about physical changes during puberty, exposure to mass media discussion activities on KKR, knowledge of the reproductive system, and risky dating behavior.

The data collection was carried out through filling in the instruments developed by the 2017 IDHS, namely, the Women of Fertile Age Questionnaire (WUS) and the Young Men Questionnaire (RP) for unmarried women and men aged 15-24 which were developed by the 2017 IDHS 2017 youth books issued by BKKBN. Data were analyzed using univariate, bivariate, and multivariate. Univariate analysis in the form of percentages, bivariate analysis using the Chi-square test to see the relationship between independent variables and dependent variables, and multivariate analysis using logistic regression tests.

\section{Results}

From Table 1 showed that the most female respondents were at $\leq 16$ years of age (98.9\%), while the most male respondents are in the age range $\geq 17$ years $(73.5 \%)$, the most respondents live is come from the city (urban) in women (53.8\%) and men (55.3\%), the education level of the most respondents is senior high school (SMA) in women $(59.5 \%)$ and men (58.6\%), knowledge about the reproductive system of female respondents was mostly at the good level of knowledge (66.9\%), while male respondents were at the most at the poor knowledge level $(79.8 \%)$, the most sexual behavior of the respondents was were at the level of sexual behavior that is not at risk for female respondents $(75.8 \%)$
Table 1: Frequency distribution of respondents by age, area of residence, education level, knowledge of reproduction, age of respondent, age at first menstruation, education level, place of residence, discussion before menstruation, age of first dating, ever using the internet $(n=23.770)$

\begin{tabular}{|c|c|c|}
\hline Variable & $f$ & $\%$ \\
\hline \multicolumn{3}{|l|}{ Age } \\
\hline \multicolumn{3}{|l|}{ Female } \\
\hline$\leq 16$ years & 10.575 & 98.9 \\
\hline$\geq 17$ years & 116 & 1.1 \\
\hline \multicolumn{3}{|l|}{ Male } \\
\hline$\leq 16$ years & 3.470 & 26.5 \\
\hline$\geq 17$ years & 9.609 & 73.5 \\
\hline \multicolumn{3}{|l|}{ Residence Area } \\
\hline \multicolumn{3}{|l|}{ Female } \\
\hline Urban & 6.391 & 59.8 \\
\hline Rural & 4.300 & 40.2 \\
\hline Male & & \\
\hline Urban & 7.237 & 55.3 \\
\hline Rural & 5.842 & 44.7 \\
\hline Education & & \\
\hline Female & & \\
\hline Primary & 383 & 3.6 \\
\hline Junior High School & 1.125 & 10.5 \\
\hline Senior High School & 6.365 & 59.5 \\
\hline Academy/DI/DII/DIII & 524 & 4.9 \\
\hline DIV/University & 2.261 & 21.2 \\
\hline Male & & \\
\hline Primary & 1.199 & 9.2 \\
\hline Junior High School & 2.135 & 16.3 \\
\hline Senior High School & 7.662 & 58.6 \\
\hline Academy/DI/DII/DIII & 281 & 2.1 \\
\hline DIV/University & 1.728 & 13.2 \\
\hline Knowledge of the Repro & & \\
\hline Female & & \\
\hline Good & 7.149 & 66.9 \\
\hline Poor & 3.509 & 32.8 \\
\hline Male & & \\
\hline Good & 2.645 & 20.2 \\
\hline Poor & 10.434 & 79.8 \\
\hline Risk Sexual Behavior & & \\
\hline Female & & \\
\hline Risk & 446 & 4.2 \\
\hline No risk & 8.100 & 75.8 \\
\hline Male & & \\
\hline Risk & 1.240 & 11.4 \\
\hline No risk & 10.845 & 88.6 \\
\hline Discussion Before Getti & & \\
\hline Female & & \\
\hline Yes & 8.281 & 77.5 \\
\hline No & 2.339 & 21.9 \\
\hline Discussion Before You & & \\
\hline Male & & \\
\hline Yes & 6.146 & 50.1 \\
\hline No & 6.122 & 49.9 \\
\hline Age for the $1^{\text {st }}$ Time to $C$ & & \\
\hline Female & & \\
\hline$\leq 16$ years & 10.575 & 98.9 \\
\hline$\geq 17$ years & 116 & 1.1 \\
\hline Age of $1^{\text {st }}$ Time Wet Dre & & \\
\hline Male & & \\
\hline$\leq 16$ years & 11.958 & 91.4 \\
\hline$\geq 17$ years & 1.121 & 8.6 \\
\hline Age for the $1^{\text {st }}$ time datir & & \\
\hline Female & & \\
\hline$\leq 16$ years & 9.294 & 73.6 \\
\hline$\geq 17$ years & 2.252 & 26.4 \\
\hline Male & & \\
\hline$\leq 16$ years & 7.972 & 73.5 \\
\hline$\geq 17$ years & 2.873 & 26.5 \\
\hline Having Sexual Intercour & & \\
\hline Female & & \\
\hline$\leq 16$ years & 5.353 & 50.1 \\
\hline$\geq 17$ years & 5.338 & 49.9 \\
\hline Male & & \\
\hline$\leq 16$ years & 1.240 & 11.4 \\
\hline$\geq 17$ years & 9.605 & 88.6 \\
\hline Internet Alertness & & \\
\hline Female & & \\
\hline Yes & 9.359 & 87.5 \\
\hline No & 1.331 & 12.4 \\
\hline Male & & \\
\hline Yes & 11277 & 86.2 \\
\hline No & 1801 & 13.8 \\
\hline Hold your boyfriend/girlf & & \\
\hline Female & & \\
\hline Yes & 9.359 & 87.5 \\
\hline No & 1.331 & 12.4 \\
\hline Male & & \\
\hline Yes & 9.715 & 89.6 \\
\hline No & 1.120 & 10.3 \\
\hline
\end{tabular}


Table 1: (continued)

\begin{tabular}{lll}
\hline Variable & $\mathrm{f}$ & $\%$ \\
\hline Hugging boyfriend/Girlfriend & & \\
Female & & \\
Yes & 3.224 & 37.7 \\
$\quad$ No & 5.315 & 62.2 \\
Male & 6.478 & 59.7 \\
$\quad$ Yes & 4.357 & 40.2 \\
$\quad$ No & & \\
Kissing boyfriend/girlfriend on the lips & & \\
Female & 1.839 & 21.5 \\
$\quad$ Yes & 6.701 & 78.4 \\
$\quad$ No & & \\
Male & 4.509 & 41.6 \\
$\quad$ Yes & 6.325 & 58.3 \\
$\quad$ No & & \\
Touching sensitive body areas of boyfriend/girlfriends & & \\
Female & 619 & 7.2 \\
$\quad$ Yes & 7.919 & 92.7 \\
$\quad$ No & & \\
Male & 3.036 & 28.0 \\
$\quad$ Yes & 7.793 & 71.9 \\
$\quad$ No & & \\
\hline
\end{tabular}

and male respondents $(88.6 \%)$, female respondents were given a discussion before getting their first menstruation $(77.5 \%)$, while male respondents- men given discussion before getting wet dreams (50.1\%), age female respondents had their first menstruation at the age of $\leq 16$ years (98.9\%), this age corresponds to the $1^{\text {st }}$ time male respondents experienced wet dreams, namely $\leq 16$ years $(91.4 \%)$, while the age at first dating was the most $\leq 16$ years for female respondents $(73.6 \%)$ and male respondents $(73.5 \%)$, the age at first sexual intercourse among female respondents was $\leq 16$ years $(50.1 \%)$ and male respondents $\geq 17$ years $(88.6 \%)$, female respondents have used the internet $(87.5 \%)$ while male respondents $(86.2 \%)$, female respondents have held the hand of a boyfriend $(87.5 \%)$ while male respondents $(89.6 \%)$, female respondents have never hugged their boyfriends $(62.2 \%)$ while male respondents have hugged their girlfriends $(59.7 \%)$, female and male respondents have never kissed their boyfriend's lips and touched sensitive body areas boyfriend $(78.4 \%)$ and $(92.7 \%)$ for female respondents as well as $92.7 \%$ (7,919 respondents) and $71.9 \%$ (7,793 respondents $n$ male).

Table 2 showed that among male respondents there was a relationship between knowledge of reproduction and sexual behavior $(p=0.000)$, there was a relationship between age and sexual behavior $(p=0.000)$, there was a relationship between education level and sexual behavior $(p=0.000)$, There was a relationship between residence and sexual behavior ( $p=0,000)$, there was a relationship between discussions before wet dreams and sexual behavior $(p=0,000)$, there was a relationship between age at first wet dreams and sexual behavior $(p=0,000)$, there was a relationship between age dating for the $1^{\text {st }}$ time with sexual behavior ( $p=0.002$ ), and there was a relationship between internet use and sexual behavior $(p=0.000)$. Whereas for female respondents there was a relationship between knowledge of reproduction and sexual behavior ( $p=0.012)$, there was a relationship between age and sexual behavior ( $p=0.000)$, there was a relationship between education level and sexual
Table 2: Relationship between sexual behavior and knowledge about reproduction, age of respondent, age at first menstruation, level of education, place of residence, discussion before menstruation, age at first dating, ever using the internet $(n=23.770)$

\begin{tabular}{|c|c|c|c|}
\hline \multirow[t]{2}{*}{ Variable } & \multicolumn{2}{|c|}{ Sexual Behavior } & \multirow[t]{2}{*}{$\mathrm{p}$} \\
\hline & Risk & No risk & \\
\hline \multicolumn{4}{|c|}{ Reproductive Knowledge * } \\
\hline \multicolumn{4}{|l|}{ Female } \\
\hline Good & 178 & 2.763 & \multirow[t]{2}{*}{0.012} \\
\hline Poor & 267 & 5.323 & \\
\hline \multicolumn{4}{|l|}{ Male } \\
\hline Good & 322 & 2.336 & \multirow[t]{2}{*}{0.000} \\
\hline Poor & 918 & 8.509 & \\
\hline \multicolumn{4}{|l|}{ Respondent Age } \\
\hline Female & & & \\
\hline$\leq 16$ years & 50 & 2.105 & \multirow[t]{2}{*}{0.000} \\
\hline$\geq 17$ years & 396 & 5.995 & \\
\hline \multicolumn{4}{|l|}{ Male } \\
\hline$\leq 16$ years & 61 & 2.230 & \multirow[t]{2}{*}{0.000} \\
\hline$\geq 17$ years & 1.179 & 7.375 & \\
\hline \multicolumn{4}{|l|}{ First Age Menstruation } \\
\hline Female & & & \\
\hline$\leq 16$ years & 738 & 8.020 & \multirow[t]{2}{*}{0.101} \\
\hline$\geq 17$ years & 8 & 80 & \\
\hline Level of education & & & \\
\hline Female & & & \\
\hline Primary & 15 & 259 & 0.037 \\
\hline Junior High School & 40 & 259 & \\
\hline Senior High School & 232 & 4.767 & \\
\hline Academy/DI/DII/DIII & 29 & 4.767 & \\
\hline DIV/University & 129 & 1.882 & \\
\hline Male & & & \\
\hline Primary & 162 & 737 & 0.000 \\
\hline Junior High School & 195 & 1.400 & \\
\hline Senior High School & 614 & 5.836 & \\
\hline Academy/DI/DII/DIII & 42 & 222 & \\
\hline DIV/University & 222 & 1.374 & \\
\hline Residence & & & \\
\hline Female & & & \\
\hline Urban & 298 & 4907 & 0.009 \\
\hline Rural & 148 & 3193 & \\
\hline Male & & & \\
\hline Urban & 636 & 6.204 & 0.000 \\
\hline Rural & 604 & 4.641 & \\
\hline Discussion before men & & & \\
\hline Female & & & \\
\hline Ya & 363 & 6.381 & 0.206 \\
\hline Tidak & 83 & 1.708 & \\
\hline Discussion Before Wet & & & \\
\hline Male & & & \\
\hline Yes & 704 & 4699 & 0.000 \\
\hline No & 501 & 4521 & \\
\hline Age of First Wet Dream & & & \\
\hline Male & & & \\
\hline$\leq 16$ years & 1062 & 8768 & 0.000 \\
\hline$\geq 17$ years & 178 & 837 & \\
\hline Age of First Dating & & & \\
\hline Female & & & \\
\hline$\leq 16$ years & 328 & 5.966 & 0.958 \\
\hline$\geq 17$ years & 118 & 2.134 & \\
\hline Male & & & \\
\hline$\leq 16$ years & 867 & 7.972 & 0.002 \\
\hline$\geq 17$ years & 373 & 2.873 & \\
\hline Ever Used the Internet & & & \\
\hline Female & & & \\
\hline Yes & 402 & 7.379 & 0.487 \\
\hline No & 44 & 721 & \\
\hline Male & & & \\
\hline Yes & 1080 & 8.715 & 0.000 \\
\hline No & 159 & 890 & \\
\hline
\end{tabular}

behavior ( $p=0.037$ ), and there was a relationship between places. Lived with sexual behavior $(p=0.009)$.

Based on Table 3 above, it was found that male respondents had a chance of 1,322 about knowledge of the reproductive system compared to female respondents who only had a chance of 0.779 , age for male respondents had a chance of 0.171 times and 0.360 in female respondents indicated that the age group was $\leq 16$ years and have a greater risk of sexual behavior, residence has a chance of 0.763 for men and 1.310 for women means that both men and women have a greater chance of experiencing the risk of sexual 
Table 3: Logistic Regression Test Results

\begin{tabular}{|c|c|c|c|c|c|c|c|c|}
\hline \multirow[t]{2}{*}{ Variable } & \multirow[t]{2}{*}{$\mathrm{B}$} & \multirow[t]{2}{*}{ S.E } & \multirow[t]{2}{*}{ Wald } & \multirow[t]{2}{*}{ df } & \multirow[t]{2}{*}{ Sig $(p)$} & \multicolumn{3}{|c|}{ 95\% C.I.for EXP (B) } \\
\hline & & & & & & $\operatorname{Exp}(\mathrm{B})$ & Lower & Upper \\
\hline \multicolumn{9}{|l|}{ Knowledge about Reproduction } \\
\hline Female & -0.250 & 0.100 & 6.318 & 1 & 0.012 & 0.779 & 0.641 & 0.946 \\
\hline Male & 0.279 & 0.069 & 16.161 & 1 & 0.000 & 1.322 & 1.154 & 1.515 \\
\hline \multicolumn{9}{|l|}{ Respondent Age } \\
\hline Female & -1.023 & 0.152 & 45.154 & 1 & 0.000 & 0.360 & 0.267 & 0.485 \\
\hline Male & -1.765 & 0.134 & 174.851 & 1 & 0.000 & 0.171 & 0.132 & 0.222 \\
\hline First Age Menstruation & -0.605 & 0.374 & 2.615 & 1 & 0.106 & 0.546 & 0.262 & 1.137 \\
\hline \multicolumn{9}{|l|}{ Level of education } \\
\hline Female & -0.110 & 0.046 & 5.673 & 1 & 0.017 & 0.895 & 0.818 & 0.981 \\
\hline Male & 0.036 & 0.029 & 1.531 & 1 & 0.216 & 1.037 & 0.979 & 1.097 \\
\hline \multicolumn{9}{|l|}{ Residence } \\
\hline Female & 0.270 & 0.103 & 6.867 & 1 & 0.009 & 1.310 & 1.070 & 1.604 \\
\hline Male & -0.270 & 0.060 & 19.931 & 1 & 0.000 & 0.763 & 0.678 & 0.859 \\
\hline Discussion before menstruation & 0.158 & 0.125 & 1.597 & 1 & 0.206 & 1.171 & 0.917 & 1.495 \\
\hline Discussion Before Wet Dreams & 0.263 & 0.061 & 18.395 & 1 & 0.000 & 1.301 & 1.153 & 1.467 \\
\hline The First Age of Wet Dreams & -0.563 & 0.089 & 40.272 & 1 & 0.000 & 0.570 & 0.479 & 0.678 \\
\hline \multicolumn{9}{|l|}{ Age of First Dating } \\
\hline Female & -0.006 & 0.110 & 0.003 & 1 & 0.958 & 0.994 & 0.801 & 1.234 \\
\hline Male & -0.201 & 0.066 & 9.239 & 1 & 0.002 & 0.818 & 0.718 & 0.931 \\
\hline \multicolumn{9}{|l|}{ Ever Used the Internet } \\
\hline Female & -0.113 & 0.164 & 0.482 & 1 & 0.488 & 0.893 & 0.648 & 1.230 \\
\hline Male & -0.384 & 0.087 & 19.409 & 1 & 0.000 & 0.681 & 0.574 & 0.808 \\
\hline
\end{tabular}

behavior, the level of education of male respondents has a greater chance of 1,037 greater than the female respondents who only had a chance of 0.895 , the age of first dating the female respondents had a chance of 0.994 greater than the male respondents who had a chance of 0.818 , while the use of the internet for male respondents had a chance of 0.893 greater than that of the male respondents. The number of female respondents was 0.681 , in addition, male respondents had a greater chance of risky sexual behavior such as discussions before wet dreams 1.301, and the first age of wet dreams was 0.570. Meanwhile, female respondents had opportunities for risky sexual behavior such as discussions before menstruation 1,171, and the first age of menstruation had a chance of 0.546 .

Table 4 showed that the factor that most influences female respondents was age $(p=0.000)$ with a chance of 0.363 indicating that age of female respondents has a smaller effect when compared to male respondents, and the factor that most influences female respondents was the place of residence $(p=0.032)$ with a chance of 1.251 indicated that place of residence has a strong influence on sexual behavior among adolescents, while the factor affecting male respondents was knowledge $(p=0.003)$ with a chance of 1.240 when compared to female respondents, age $(p=0.000)$ with a chance of 0.165 indicating that the age of the male respondents has a big influence on sexual behavior, age at first dating $(p=0.019)$ with a chance of 1.178, place of residence $(p=0.000)$ with a chance of 0.788 indicating that the influence on sexual behavior, discussion before wet dreams $(p=0.000)$ with a chance of 1,320 first age wet dreams $(p=0.000)$ has a chance of 0.693 which indicates that age in male respondents has a greater influence on sexual behavior, as well as internet use $(p=0.000)$ chance of 0.622 indicates that the use of the internet during adolescence affects the risk of sexual behavior.

In theory, logistic regression analysis can be analyzed from the $p$ value (sig) and $\operatorname{Exp}(B)$, where if the $p$-value $\leq 0.05$ the variable will have an influence on the dependent variable; the magnitude of the effect can be predicted through the $\operatorname{Exp}(B)$ value. However, if the $p$-value $>0.05$ in theory the independent variable can have an influence on the dependent variable, logostic regression analysis can be carried out with the $\operatorname{Exp}(B)$ value by ignoring the $p$ value, where the $\operatorname{Exp}(B)$ value was $\geq 1.5$.

Based on the value of Exp (B) it can be concluded that:

\section{Female respondents}

a) Odd ratio (OR) of sexual behavior about age $=0.363$, indicating that respondents who were $<16$ years old have a 0.363 times greater influence on sexual behavior when compared to those who were more than 17 years old

Table 4: Multivariate analysis the influence of knowledge about the reproductive system, age, education level, and place of residence

\begin{tabular}{|c|c|c|c|c|c|c|c|c|}
\hline \multirow[t]{2}{*}{ Variable } & \multirow[t]{2}{*}{$\mathrm{B}$} & \multirow[t]{2}{*}{ S.E } & \multirow[t]{2}{*}{ Wald } & \multirow[t]{2}{*}{$\mathrm{df}$} & \multirow[t]{2}{*}{ Sig $(p)$} & \multicolumn{3}{|c|}{ 95\% C.I.for EXP (B) } \\
\hline & & & & & & Exp (B) & Lower & Upper \\
\hline \multicolumn{9}{|l|}{ Female } \\
\hline Age & -1.014 & 0.157 & 41.578 & 1 & 0.000 & 0.363 & 0.267 & 0.494 \\
\hline Residence & 0.224 & 0.105 & 4.590 & 1 & 0.032 & 1.251 & 1.019 & 1.536 \\
\hline \multicolumn{9}{|l|}{ Male } \\
\hline Knowledge & 0.215 & 0.072 & 8.848 & 1 & 0.003 & 1.240 & 1.076 & 1.428 \\
\hline Age & -1.801 & 0.144 & 156.953 & 1 & 0.000 & 0.165 & 0.125 & 0.219 \\
\hline Age for first dating & 0.164 & 0.070 & 5.470 & 1 & 0.019 & 1.178 & 1.027 & 1.352 \\
\hline Residence & -0.238 & 0.063 & 14.052 & 1 & 0.000 & 0.788 & 0.696 & 0.893 \\
\hline Discussion about wet dreams & 0.278 & 0.063 & 19.346 & 1 & 0.000 & 1.320 & 1.167 & 1.494 \\
\hline The first age of wet dreams & -0.367 & 0.092 & 15.796 & 1 & 0.000 & 0.693 & 0.578 & 0.830 \\
\hline Ever Used the Internet & -0.476 & 0.097 & 24.152 & 1 & 0.000 & 0.622 & 0.514 & 0.751 \\
\hline
\end{tabular}


b) OR of sexual behavior about place of residence $=1.251$ indicating that the place where the respondent lives in the city has an influence on sexual behavior 1,251 times greater when compared to respondents who live in the village.

\section{Male respondents}

a) OR of sexual behavior regarding knowledge of reproductive health $=1.240$, indicating that the respondent's poor knowledge has an influence on sexual behavior 1,240 times greater when compared to respondents who have good knowledge

b) OR of sexual behavior about age $=0.165$, indicating that respondents who were more than 17 years old have a 0.165 times greater influence on sexual behavior when compared to those who were $<16$ years old

c) OR of sexual behavior regarding age at first dating $=1.178$ indicating that respondents who had a boyfriend at the age of $<16$ years had an influence on sexual behavior 1,178 times greater when compared to respondents who were dating at the age of more than 17 year

d) OR of sexual behavior about residence $=0.788$, indicating that respondents who live in cities have a 0.788 times greater influence on sexual behavior when compared to respondents who live in villages

e) OR of sexual behavior about discussions before wet dreams $=1.320$, indicating that respondents who were given discussions before wet dreams had a 1.320 times greater influence on sexual behavior when compared to respondents who were not given discussions about wet dreams

f) OR of sexual behavior regarding the first age of wet dreams $=0.693$ indicating that respondents who experienced wet dreams were $<16$ years old had an influence on sexual behavior 0.693 times greater when compared to respondents who had wet dreams for more than 17 years

g) OR of sexual behavior about the first age of wet dreams $=0.693$ indicating that respondents who experienced wet dreams were $<16$ years of age had an influence on sexual behavior 0.693 times greater when compared to respondents who had wet dreams for more than 17 years

h) OR of sexual behavior about having used the internet $=0.622$ indicating that respondents who have used the internet have 0.622 times greater sexual behavior when compared to respondents who do not use the internet.

\section{Discussion}

\section{Hubungan antara pengetahuan tentang reproduksi dengan perilaku seksual}

Based on Table 5.2, it shows that there was a relationship between knowledge of reproduction and sexual behavior $(p=0.000)$, in male respondents with a greater chance of 1,322 than female respondents. The results showed that most female respondents had good knowledge about the reproductive system (66.9\%), while male respondents were mostly at the poor knowledge level $(79.8 \%)$. In this case, adolescents who have a good level of knowledge will understand the bad effects of sexual behavior, while adolescents who have low knowledge will influence adolescents' attitudes toward sex and risky sexual behavior [25].

Adolescents are one of the groups with special needs in the field of sexual and reproductive health, because these adolescents are not only often involved in risky sexual behavior but also lack of information and access to reproductive health services, causing these adolescents to be less exposed to the information they should get. Adolescents who lack knowledge about sex and sexuality will tend to engage in sexual activity that was reckless and unattended so that it will have a negative impact on these adolescents [26].

Indonesia was one of the countries that still consider taboo regarding the discussion of sexuality and reproductive health behavior in the family, school, and community environment. However, in the current era of globalization, western culture has a lot of influence and brings freedom and very open access to any information. This situation will have a negative impact on adolescents with the emergence of reproductive health behaviors that can be carried out actively and freely, this will worsen the situation if these adolescents are not given prior knowledge about sexual behavior [27]. In contrast to Indonesia, one school in the UK has used a curriculum for its students, which includes sex education in subjects such as life skills, social sciences, integrated science, including sexual and reproductive health education in Biology. From this subject matter, efforts to address issues concerning sexually transmitted infection, HIVIAIDS, and teenage pregnancy were given to adolescents who were in education. In addition, there have been several programs that have been disseminated on television and radio stations targeting youth groups; the aimed of this program was to provide adolescents with adequate knowledge about issues of sex and sexuality [28].

\section{behavior}

The relationship between age and sexual

Based on Table 1, it showed that the riskiest sexual behavior among female respondents was at the 
age of $<16$ years with a percentage of $98.9 \%(10,575$ respondents), while most male respondents were in the age range more than 17 years with a percentage of 73 , $5 \%(9,609$ respondents). Table 5.2 shown that there was a relationship between age and sexual behavior ( $p$ $=0.000$ ) in male and female respondents. Based on the table above, age has a chance of 0.171 times for male respondents and 0.360 for female respondents, this indicated that the age group $<16$ years has a greater risk of engaging in risky sexual behavior.

It was in accordance with [29] who conducted a study on 258 adolescents, where (7.5\%) had made their sexual debut before the age of 14 years (7.8\% girls and $7.2 \%$ boys), as many as 2211 (64.4\%) had made sexual debuts at the age of more than 14 years (66.4\% female and $62.2 \%$ male) and as many as $963(21.1 \%)$ have not yet made their sexual debut (25.8\% female and $30.7 \%$ male). The mean age of adolescents making sexual debut was 15.4 years, with a standard deviation (SD) of 1.5 for the total sample. In the study, it was found that girls had an earlier sexual debut, with a mean age of 15.3 years $(S D=1.47)$, than boys, with a mean age of 15.5 years $(S D=1.53)$. This study was in accordance with [30] which states that there was a relationship between the age of adolescent girls at earlier menarche with sexual behavior, where the early menarche group had more experience in kissing and caressing the opposite sex than the group who experienced menarche at normal age (OR, 1 54; 95\% confidence interval [Cl], 1.28-1.87). In addition, the group who experienced menarche earlier had more experience with intercourse than the normal menarche group (OR, 2.35; 95\% Cl, 1.65-3.36). Even adolescents in the early menarche group had more experiences of being victims of sexual violence (OR, 2.89; 95\% Cl, 1.98-4.22) and being perpetrators of sexual violence (OR, 13.55; 95\% Cl, 6.61-27.78) than the normal age menarche group. In addition, the early menarche group experienced more sexual intercourse without using contraception (OR, 1.92; 95\% Cl, 1.06-3.46) so that there was a higher risk of pregnancy (OR, 5.72; 95\% Cl, 2.31-14.15).

In this case, sexual behavior among adolescents will become a concern, especially if the behavior was risky. The most frequent indicator of risky sexual behavior was having intercourse for the $1^{\text {st }}$ time at a young age [31]. Age and experience for the $1^{\text {st }}$ time in sexual behavior can affect the satisfaction experienced by a person in the following years. A positive first sexual experience will be associated with physical and emotional satisfaction at subsequent opportunities [32]. Meanwhile, the first negative sexual experience will damage the self-image of adolescents [33]. Adolescents who engage in sexual behavior for the $1^{\text {st }}$ time at an early age will experience signs and symptoms such as depression, distorted patient self-image [33], attention deficit, tendency to have naughty, aggressive behavior, difficulty in interacting with others [34], and regret about initiating sexual behavior due to partner pressure or impulsivity [35].

\section{The relationship between education level and sexual behavior}

The education level of respondents was a factor related to sexual behavior, based on Table 5.1; most respondents were in SMA education with a percentage of $59.5 \%$ female $(6,365$ respondents) and $58.6 \%$ male (7,662 respondents). The results showed that there was a relationship between the level of education and sexual behavior with a chance of 1.037 indicating that the level of education of male respondents was much greater than that of female respondents. The results of this study are in accordance with [36] stating that nearly $30 \%$ of students in the comparison group started premarital sexual behavior in the ninth grade, compared to $23 \%$ of students in the intervention group, even though that comparison had a 1.76 times greater risk of initiating oral sex and 2.67 times greater to initiating oral sex. Exposure to premarital sexual behavior that was carried out orally and anally was increasing among adolescents and young adults [37]. However, until now no high school age program has addressed or directly evaluated the results of anal and oral sex. Research shows that teens perceive oral sex to have fewer health consequences than vaginal sex [38].

\section{The relationship between residence and sexual behavior}

Based on Table 5.2, it showed that there was a relationship between residence and sexual behavior with a $\mathrm{p}$-value $=0.000$ for male respondents and a $p$-value $=0.009$ for female respondents with an opportunity of 0.763 for men and 1.310 for women, so that both men and women. Women have a greater chance to experience the risk of sexual behavior with the percentage of respondents mostly coming from cities (urban) with a percentage of women $53.8 \%(6,391$ respondents) and men $55.3 \%$ (7,237 respondents). This was in accordance with the research [39] which stated that there was a relationship between residence and risky sexual behavior with the percentage (39.6\%) of adolescents who live in urban areas and $(60.4 \%)$ of adolescents who live in rural areas with $p$ value $=0.03$ and $(\mathrm{OR}=1.68,95 \% \mathrm{Cl}(1.04,2.70)$ for adolescents living in rural areas, so it can be concluded that adolescents in rural areas have a higher likelihood of initiating sexual intercourse than adolescents living in urban areas [40] which stated that there was a relationship between adolescents and parents who live in rural areas with a percentage of $49.2 \%$ (OR 1.92; 95\% Cl: 1.28-2.94), adolescents whose parents lived in rural areas have a higher chance of engaging in sexual activity than adolescents who lived in rural areas. his parents live 
in urban areas. This could be because youth from rural areas lack adequate access to information related to reproductive health and risky sexual behavior. Adolescents living in cities have greater knowledge of reproductive health than adolescents who live in rural areas [41].

\section{The relationship between age at first dating and sexual behavior}

The hallmark of psychological maturity was marked by the emergence of its own pleasure when associating with the opposite sex and arriving at behavior that has become a common consumption, namely dating. Based on Table 5.2, it showed that there was a relationship between age at first dating with sexual behavior $(p=0.002)$, with a chance of 0.818 and the percentage of dating age at most, which was $<16$ years for female respondents $(73.6 \%)$ and male respondents (73.5\%). Research result [42] conducted on students in grades six, seven, and eight showed that on average students at that age were familiar with dating. Where the percentage showed $868(30.6 \%)$ in sixth grade students, $911(32.1 \%)$ in seventh grade students, and 1,057 (37.3\%) in eighth grade students. Of the 1,653 students who were already dating, $77 \%$ reported verbal/emotional abuse, $33 \%$ reported physical abuse, 20\% reported engaging in threatening behavior, $15 \%$ reported sexual assault, $13 \%$ reported aggressive behavior, and $6 \%$ reported stalking a partner. Beside that the research [43] showed that there was a relationship between age at first dating with sexting behavior, where in younger girls will have more emotional problems associated with the likelihood of involvement almost 3 times greater in sexting with a score $(O R=2.91 ; p<0.001)$. Meanwhile, male adolescents who were younger were 3 times more likely to engage in sexting $(\mathrm{OR}=2.89 ; \mathrm{p}<0.001)$.

Since the last decade, the involvement of adolescents in having romantic relationships (dating) and sexual activities has been increasing, and this involvement was considered a normative aspect because adolescents are experiencing development towards young adulthood [44]. This indicated that relationships and sexuality were related to the expected behavior patterns from adolescents to young adulthood, as evidenced by prevalence statistics from many countries in the west (United States, United Kingdom, and the Netherlands) showing that more than half of adolescents report having had intercourse sexuality by the time they were 18 years of age [45], [46], [47].

\section{sexual behavior \\ The relationship between internet use and}

The use of the internet or online communication was a trending phenomenon, especially among adolescents. At present, many teenagers were involved in online social networking, both as producers and as users of online information [48], [49]. However, the use of the internet was often used by teenagers to provide information about their personalities to others who may not be very well known [50]. Teens, who use the internet to communicate online with strangers, will pose risks to the teenagers themselves, such as sexual harassment conducted online [51] or directly access dangerous content and content that violates privacy [52].

Based on Table 5.2 showed that there was a relationship between internet use and sexual behavior $(p=0.000)$ with a chance of 0.681 indicating that internet use during adolescence has an influence on sexual behavior with the presentation of internet use in female respondents who have used the internet $(87.5 \%)$ while male respondents $(86.2 \%)$. The results of previous research indicate that there are gender differences when adolescents engage in risky sexual behavior, where initially male adolescents only seek sensations when engaging in risky sexual behavior, for example, the use of alcohol or never being present at school [53]. However, nowadays, risky sexual behavior among male adolescents has changed, namely that the goal of male adolescents in consuming alcohol was to have anal intercourse with the same sex [54]. In addition, teenage boys will usually deliberately expose and reveal information about their personalities online [55]. In contrast to girls who are affected by acts of risky sexual behavior, teenage girls will usually tell when their online communication results in unwanted situations [56].

In fact, there were many benefits that can be obtained from using information through internet access, including obtaining information anytime and anywhere, and only required the support of mobile devices such as smartphones or android phones, laptops, computers, tablets, and iPhones [57]. However, the use of smartphones and the internet in adolescents was often used to interact with known and unknown friends to build and maintain social relationships [58]. Such communication takes place independently from time and place and was relatively easy to use, online interaction was a new way to encourage the development of adolescent identity, self-expression, intimate relationships, and social welfare [59]. Thus [60] stated that internet use cannot be generalized to adolescents aged 18 years and under, because it can increase the opportunity to access the internet without supervision, besides that it can also facilitate sexual requests made online (i.e. first approached by means of online introductions with the intention of doing sex), partner seeking, and sexual risk taking with new friends. Nearly $(80.66 \%)$ adolescents use internet access at home and one third (32.95\%) access using personal cell phones. The average intensity of internet use among adolescents was more than $1 \mathrm{~h} /$ day $(30.30 \%)$ with OR $2.07,95 \% \mathrm{Cl} 1.56-2.75$ and only about $3 \%$ 
of adolescents reported never using the internet. From the results of the study, it was also reported that there was an effect between internet use and online sex partner search $(\mathrm{OR}=2.65,95 \% \mathrm{Cl} 1.51-4.67$, $\mathrm{p}<0.001)$, and having been asked to have sex online $(\mathrm{OR}=10.12,95 \% \mathrm{Cl} 6.11-16.76, \mathrm{p}<0.001)$. From these results adolescents who were approached online for sex were almost 3 times more likely to be sexually active $(\mathrm{OR}=2.80,95 \% \mathrm{Cl} 2.06-3.81, \mathrm{p}<0.001)$ and those who reported looking for sex partners online nearly 4 times more likely to be sexually active (OR $=3.98,95 \% \mathrm{Cl} 2.11-7.48, \mathrm{p}<0.001)$.

In this case, having good communication from parents about Internet use can help teenagers to limit excessive Internet use [61]. In addition, it can help teens to be more careful in maintaining their privacy online [62]. Therefore, the existence of restrictive mediation from parents can teach adolescents valuable knowledge and skills, thereby instilling their children's resilience to online risks. Restrictive mediation from parents aims to reduce or prohibit children from behaving that they do not want. Parents are more restricting and spending time with children by watching appropriate content so as not to worry about the effects of negative media [63]. Sharing the internet between parents and children can fight risky online behavior, but it will also provide benefits for both parents and children. First, when using the internet together, parents can directly see the type of content that was accessed by children; so that children can refrain from viewing risky online sites. Second, when around children, parents can pay attention to their teen's online behavior and may indicate verbally or nonverbally which type of content they prefer [64].

\section{Conclusion}

Based on the results of the study, it can be concluded that male adolescents have many factors that influence high-risk sexual behavior than female adolescents. Therefore, information on determinant factors of high-risk adolescent sexual behavior can be used as a basis for developing policies for developing interventions in solving problems of premarital pregnancy and early marriage due to high-risk sexual behavior among adolescents, both in schools and in the community. The results of the research can also be used as a Gender Program (PIK for youth) as part of the BKKBN program. It is hoped that it can include curricula related to reproductive health and reproductive problems from the junior high school level so that adolescents can get information and form the right attitude about sexuality.

\section{References}

1. Kementrian Pemberdayaan Perempuan dan Perlindungan Anak. Profil Generasi Milenial Indonesia. Jakarta: Kementerian Pemberdayaan Perempuan dan Perlindungan Anak; 2018. https://doi.org/10.21274/martabat.2018.2.2.315-338

2. Sdki K. Survei Demografi dan Kesehatan Indonesia 2017 Kesehatan Reproduksi Remaja; 2017. Available form: http://www.dhsprogram.com/pubs/pdf/PR112.I.pdf.

3. BKKBN. Keluarga Bahagia Keluarga Berencana. Jakarta: BKKBN; 2016.

4. Santrock JW. Life-span Development, Edisi Ketigabelas. Jakarta: Erlangga; 2012

5. Hamid S. Determinan perilaku seksual berisiko pada remaja makassar (studi kasus santri darul arqam gombara dan SMAN 6). Media Kesehatan Masyarakat Indones Univ Hasanuddin. 2018;14(1):68-77. https://doi.org/10.30597/mkmi.v14i1.3699

6. Wahyuni S, Fahmi I. Determinan perilaku seksual pra nikah remaja pria di Indonesia Hasil SDKI. In: Euclid. Vol. 6. Berlin, Germany: Bayer HealthCare Pharmaceuticals; 2019. p. 177-88.

7. Control and Prevention, CDC. Youth Risk Behavior Surveillance System. United States: Control and Prevention; 2006.

8. Statistik BP. Survei Kesehatan Reproduksi Remaja Indonesia 2007. Jakarta: BPS; 2008

9. SKRRI. Kesehatan Reproduksi Remaja. Jakarta: SKRRI; 2012.

10. Prijatni I. Kesehatan Reproduksi dan Keluarga Berencana. Jakarta, Modul Bahan Ajar Cetak Kebidanan; 2016.

11. BKKBN. BKKBN Fokuskan Peningkatan Akses Dan Mutu Pelayanan Kesehatan Ibu Anak, KB dan Kesehatan Reproduksi. https://doi.org/10.34305/nnc.v1i1.131

12. World Health Organization. State of Health Inequality: Indonesia Geneva: World Health Organization; 2017.

13. Lestary $H$, Sugiharti $S$. Perilaku berisiko remaja di Indonesia menurut survey kesehatan reproduksi remaja indonesia (SKRRI) Tahun 2007. Indones J Reprod Health. 2011;1(3):136-44. https://doi.org/10.20527/jbk.v4i2.5659

14. Pradnyani PE, Putra IG, Astiti NL. Knowledge, attitude, and behavior about sexual and reproductive health among adolescents students in Denpasar, Bali, Indonesia. Global Health Manage J. 2019;3(1):31-9. https://doi.org/10.35898/ ghmj-31284

15. Septianah TI, Solehati T, Widianti E. Hubungan pengetahuan, tingkat pendidikan, sumber informasi, dan pola asuh dengan pernikahan dini pada wanita. J Riset Hesti Medan Akper Kesdam I/BB Medan. 2020;4(2):73-81. https://doi.org/10.34008/ jurhesti.v4i2.138

16. Solehati T, Ermiati E, Trisyani M, Hermayanti Y. Hubungan sumber informasi dan usia remaja puteri dengan perilaku perawatan diri saat menstruasi. J Keperawatan Padjadjaran. 2017;5(2):452. https://doi.org/10.24198/jkp.v5i2.452

17. Solehati T, Rahmat A, Kosasih CE. Hubungan media dengan sikap dan perilaku triad kesehatan reproduksi remaja relation of media on adolescents'reproductive health attitude and behaviour. J Penelitian Komunikasi Opini Publik. 2019;23(1):40-53. https:// doi.org/10.33299/jpkop.23.1.1768

18. Guo W, Nathanson Al. The effects of parental mediation of sexual content on the sexual knowledge, attitudes, and behaviors of adolescents in the US. J Child Media. 2011;5(4):358-78. https:// doi.org/10.1080/17482798.2011.587141

19. Alfiyah N, Solehati T, Sutini T. Gambaran faktor-faktor yang berhubungan dengan perilaku seksual pranikah pada remaja SMP. J Pendidikan Keperawatan Indones. 2018;4(2):10443. https://doi.org/10.17509/jpki.v4i2.10443 
20. George MJ, Odgers CL. Seven fears and the science of how mobile technologies may be influencing adolescents in the digital age. Perspect Psychol Sci. 2015;10(6):832-51. https:// doi.org/10.1177/1745691615596788

21. Solehati T, Rahmat A, Kosasih CE, Hidayati NO. Relationship between age, gender and peer group with reproductive healthy behaviour of teen. J Keperawatan Padjadjaran. 2018;6(2):643. https://doi.org/10.24198/jkp.v6i2.643

22. Coyne SM, Ward LM, Kroff SL, Davis EJ, Holmgren HG, Jensen $A C$, et al. Contributions of mainstream sexual media exposure to sexual attitudes, perceived peer norms, and sexual behavior: A meta-analysis. J Adolesc Health. 2019;64(4):430-6. https://doi.org/10.1016/j.jadohealth.2018.11.016 PMid:30691937

23. Macapagal KK, Ashley K, Moskowitz DA, Birnholtz J. Geosocial networking application use, characteristics of app-met sexual partners, and sexual behavior among sexual and gender minority adolescents assigned male at birth. J Sex Res. 2020;57(8):1078-87. https://doi.org/10.1080/00224499.2019.16 98004

\section{PMid:31846592}

24. Solehati T, Kosasih CE, Rahmat A. Hubungan sosiodemografi orang tua dengan sikap remaja tentang kesehatan reproduksi remaja. J Kesehatan. 2018;11(1):21-6. https://doi.org/10.32763/ juke.v11i1.58

25. Caetano ME, Linhares IM, Pinotti JA, da Fonseca AM, Wojitani MD, Giraldo PC. Sexual behavior and knowledge of sexually transmitted infections among university students in Sao Paulo, Brazil. Int J Gynecol Obstetr. 2010;110(1):43-6. https:// doi.org/10.1016/j.ijgo.2010.02.012

PMid:20394925

26. Rashid S, Mwale M. The effects of sex education on the risky sexual behaviour of school going adolescents: A case study of Mbenjere secondary, Ntaja and Nsanama community day secondary schools. Psychol Dev Soc. 2016;28(1):126-38. https://doi.org/10.1177/0971333615622910

27. Susanto T, Rahmawati I, Wuryaningsih EW, Saito R. Prevalence of factors related to active reproductive health behavior: A crosssectional study Indonesian adolescent. Epidemiol Health. 201638:e2016041. https://doi.org/10.4178/epih.e2016041 PMid:27866406

28. Berlin KB. Education Matters: Empowering Young People to Make Healthier Choices. Berlin, Germany:Bayer HealthCare Pharmaceuticals Social Healthcare Programs; 2011.

29. Kastbom AA, Sydsjö G, Bladh M, Priebe G, Svedin CG. Sexual debut before the age of 14 leads to poorer psychosocial health and risky behaviour in later life. Acta Paediatr. 2015;104(1):91-100. https://doi.org/10.1111/apa.12803

30. Cheong JI, Lee $\mathrm{CH}$, Park JH, Ye BJ, Kwon KA, Lee YS, et al. The effect of early menarche on the sexual behaviors of Korean female adolescents. Ann Pediatr Endocrinol Metab. 2015;20(3):130.

PMid:26512348

31. Lansford JE, Yu T, Erath SA, Pettit GS, Bates JE, Dodge KA Developmental precursors of number of sexual partners from ages 16 to 22. J Res Adolesc. 2010;20(3):651-77. https://doi. org/10.1111/j.1532-7795.2010.00654.x PMid:20823951

32. Smith CV, Shaffer MJ. Gone but not forgotten: Virginity loss and current sexual satisfaction. J Sex Marital Ther. 2013;39(2):96-111. https://doi.org/10.1080/0092623x.2012.675023 PMid:23252636

33. Vasilenko SA, Ram N, Lefkowitz ES. Body image and first sexual intercourse in late adolescence. J Adolesc. 2011;34(2):327-35. https://doi.org/10.1016/j.adolescence.2010.04.005

\section{PMid:20488512}

34. Tsitsika A, Andrie E, Deligeoroglou E, Tzavara C, Sakou I, Greydanus D, et al. Experiencing sexuality in youth living in Greece: Contraceptive practices, risk taking, and psychosocial status. J Pediatr Adolesc Gynecol. 2014;27(4):232-9. https:// doi.org/10.1016/j.jpag.2013.11.009

PMid:25016561

35. Lara LA, Abdo $\mathrm{CH}$. Age at time of initial sexual intercourse and health of adolescent girls. J Pediatr Adolesc Gynecol. 2016;29(5):417-23. https://doi.org/10.1016/j.jpag.2015.11.012 PMid:26655691

36. Tortolero SR, Markham CM, Peskin MF, Shegog R, Addy RC, Escobar-Chaves SL, et al. It's your game: Keep it real: Delaying sexual behavior with an effective middle school program. J Adolesc Health. 2010;46(2):169-79. https://doi.org/10.1016/j. jadohealth.2009.06.008 PMid:20113923

37. Lindberg LD, Jones R, Santelli JS. Noncoital sexual activities among adolescents. J Adolesc Health. 2008;43(3):231-8. https://doi.org/10.1016/j.jadohealth.2007.12.010 PMid: 18710677

38. Lefkowitz ES, Vasilenko SA, Leavitt CE. Oral vs. vaginal sex experiences and consequences among first-year college students. Arch Sex Behav. 2016;45(2):329-37. https://doi. org/10.1007/s10508-015-0654-6

39. Abate BB, Kassie AM, Kassaw MW. Prevalence and determinants of early initiation of sexual intercourse among youth girls in Ethiopia. J Pediatr Nurs. 2020;55:e305-12. https:// doi.org/10.1016/j.pedn.2020.06.008 PMid:32736839

40. Salih NA, Metaferia H, Reda AA, Biadgilign S. Premarital sexual activity among unmarried adolescents in Northern Ethiopia: A cross-sectional study. Sex Reprod Healthc. 2015;6(1):9-13. https://doi.org/10.1016/j.srhc.2014.06.004 PMid:25637418

41. Mohammed S, Susuman S. Factors associated with level of reproductive health information in Ethiopia. Asia Pac J Res. 2013;2:8.

42. Niolon $\mathrm{PH}$, Vivolo-Kantor AM, Latzman NE, Valle LA, Kuoh $\mathrm{H}$ Burton $\mathrm{T}$, et al. Prevalence of teen dating violence and co-occurring risk factors among middle school youth in highrisk urban communities. J Adolesc Health. 2015;56(2):S5-13. https://doi.org/10.1016/j.jadohealth.2014.07.019 PMid:25620454

43. Sevcikova A. Girls' and boys' experience with teen sexting in early and late adolescence. J Adolesc. 2016;51:156-62. https:// doi.org/10.1016/j.adolescence.2016.06.007 PMid:27391169

44. Tolman DL, McClelland SI. Normative sexuality development in adolescence: A decade in review, 20002009. J Res Adolesc. 2011;21(1):242-55. https://doi. org/10.1111/j.1532-7795.2010.00726.x

45. Martinez G, Copen CE, Abma JC. Teenagers in the United States; sexual activity, contraceptive use, and childbearing, 2006-2010 national survey of family growth. Vital Health Stat. 2011;31:1-35.

PMid:22256688

46. Field N, MercerCH, Sonnenberg P, Tanton C, Clifton S, MitchellKR, et al. Associations between health and sexual lifestyles in Britain: Findings from the third national survey of sexual attitudes and lifestyles (natsal-3). Lancet. 2013;382(9907):1830-44. https:// doi.org/10.1016/s0140-6736(13)62222-9

47. Graaf HD, Kruijer H, Acker J, Meijer S. Seks Onder Je 25ste: Seksuele Gezondheid van Jongeren in Nederland Anno 2012. Delft: Eburon; 2012. https://doi.org/10.1007/s12508-012-0080-2

48. Lenhart A, Purcell K, Smith A, Zickuhr K. Social Media and 
Mobile Internet Use Among Teens and Young Adults. United States: Millennials: Pew Internet and American Life Project; 2010.

49. Valkenburg PM, Peter J. Online communication among adolescents: An integrated model of its attraction, opportunities, and risks. J Adolesc Health. 2011;48(2):121-7. https://doi. org/10.1016/j.jadohealth.2010.08.020

PMid:21257109

50. Shin W, Huh J, Faber RJ. Tweens' online privacy risks and the role of parental mediation. J Broadcast Electron Media. 2012;56(4):632-49. https://doi.org/10.1080/08838151.2012.732 135

51. Görzig A, Ólafsson K. What makes a bully a cyberbully? Unravelling the characteristics of cyberbullies across twenty-five European countries. J Child Media. 2013;7(1):9-27. https://doi. org/10.1080/17482798.2012.739756

52. Lobe B, Livingstone S, Ólafsson K, Vodeb K. Cross-national Comparison of Risks and Safety on the Internet. London: LSE, EU Kids Online; 2011.

53. Junger-Tas J, Ribeaud D, Cruyff MJ. Juvenile delinquency and gender. Eur J Criminol. 2004;1(3):333-75. https://doi. org/10.1177/1477370804044007

54. Heidinger B, Gorgens K, Morgenstern J. The effects of sexual sensation seeking and alcohol use on risky sexual behavior among men who have sex with men. AIDS Behav. 2015;19(3):431-9. https://doi.org/10.1007/s10461-014-0871-3 PMid:25096894

55. Sasson H, Mesch G. Parental mediation, peer norms and risky online behavior among adolescents. Comput Hum Behav. 2014;33:32-8. https://doi.org/10.1016/j.chb.2013.12.025

56. Baumgartner SE. Adolescent Sexual Risk Behavior on the Internet. Netherlands: Universiteit van Amsterdam; 2013.

57. Gikas JG, Michael M. Mobile computing devices in higher education: Student perspectives on learning with cellphones, smartphones and social media. Internet Higher Educ. 2013;19:18-26. https://doi.org/10.1016/j.ineduc.2013.06.002

58. Lenhart A. Teens, Smartphones and Texting. United States: Pew Research Center's Internet and American Life Project; 2012.

59. Houlihan D, Houlihan M. Adolescents and the social media: the coming storm. J Child Adolescent Behav. 2014;2(2):e105. https://doi.org/10.4172/2375-4494.1000e105

60. Rice E, Winetrobe H, Holloway IW, Montoya J, Plant A, Kordic T. Cell phone internet access, online sexual solicitation, partner seeking, and sexual risk behavior among adolescents. Arch Sex Behav.2015;44(3):755-63. https://doi.org/10.1007/ s10508-014-0366-3

PMid:25344027

61. van Den Eijnden RJ, Spijkerman R, Vermulst AA, van Rooij TJ, Engels RC. Compulsive Internet use among adolescents: Bidirectional parent-child relationships. J Abnorm Child Psychol. 2010;38(1):77-89. https://doi.org/10.1007/ s10802-009-9347-8

PMid: 19728076

62. Liu C, Ang RP, Lwin MO. Cognitive, personality, and social factors associated with adolescents' online personal information disclosure. J Adolesc. 2013;36(4):629-38. https://doi. org/10.1016/j.adolescence.2013.03.016

PMid:23849657

63. Nikken P, Jansz J. Developing scales to measure parental mediation of young children's internet use. Learn Media Technol. 2014;39(2):250-66. https://doi.org/10.1080/17439884. 2013.782038

64. Notten N, Nikken P. Boys and girls taking risks online: A gendered perspective on social context and adolescents' risky online behavior. New Media Soc. 2016;18(6):966-88. https://doi. org/10.1177/1461444814552379 